\title{
Biosynthesis of Growth Hormone and Insulin-Like Growth Factor-I and the Regulation of their Secretion
}

\author{
A. Skottner*
}

AstraZeneca R\&D, Södertälje, Sweden

\begin{abstract}
This report reviews the current knowledge on the biosynthesis, regulation and secretion of Growth Hormone (GH) and Insulin-like Growth factor-I (IGF-I). Variants of human GH, molecular size variants as well as charge variants, and the GH binding protein will be discussed, and the regulation of expression of the $h G H$ gene is reviewed. IGF-I expression, regulation of the igf-I gene and secretion is discussed and a separate section on the influence of the six IGF binding proteins is included.
\end{abstract}

Keywords: hGH, IGF-I, biosynthesis, secretion, regulation, binding proteins.

\section{INTRODUCTION}

Both GH and IGF-I play important roles in growth and metabolism throughout life. $\mathrm{GH}$ is essential for postnatal growth in all species, but does also exert important peripheral effects on energy metabolism, body composition, bone metabolism, immune system, muscle function as well as on the central nervous system (CNS), affecting e.g. appetite, cognition and sleep. IGF-I is a mitogen and stimulator of cell proliferation, and has important functions in tissue repair and regenerative processes. It also mediates some of the anabolic and growth activities of GH.

Much information on how and where these hormones are produced in the body and the regulation of their expression, as well as how and where GH and IGF-I exert their biological action has been gathered. Specific receptors in certain tissues and cells have been identified, and soluble binding proteins carrying the peptides in plasma, prolonging the half-lives and making the active peptides available or inhibiting their actions have been established. Results from in vitro studies in different cell types, studies in experimental animals, the use of transgenic techniques and human clinical trials, have revealed the importance of GH and IGF-I in many physiological functions, not only growth and metabolism, but also on development, regeneration and the immune system. It is also evident that both GH and IGF-I have important actions in the neurological system, both in the CNS and peripheral nervous system, impacting development, cognition and mood, and exerting neuroprotective activity. This Chapter gives a brief overview of the current knowledge on the expression of GH and IGF-I and the regulation of their secretion.

\footnotetext{
*Address correspondence to this author at the AstraZeneca R\&D, Regulatory Affairs, B213, Forskargatan 20, SE-15185 Södertälje, Sweden; Tel: +46855324144; Fax: +468555328909;

E-mail: anna.skottner@astrazeneca.com
}

\section{GROWTH HORMONE}

The first signs of a pituitary factor involved in growth were already identified a century ago by Crowe et al. [1], who described the induction of growth arrest after hypophysectomy. Later, Evans [2,3] reported that administration of bovine pituitary extracts restored growth in female rats, and that a 'growth hormone' would be contained in the pituitary. Human $\mathrm{GH}(\mathrm{hGH})$ was first isolated by $\mathrm{Li}$ and coworkers [4] and the structure of the peptide was elucidated [5]. Human GH is a single chain peptide, comprising 191 amino acid residues, with two disulphide bonds and a molecular weight of 22,000 daltons $(22 \mathrm{~K})$. The human $\mathrm{GH}$ gene is found on the long arm of chromosome 17. Two different loci coding for hGH were identified in the gene cluster, $h G H-N$ and $h G H-V$ [6]. The corresponding peptides resulting from these genes are highly homologous but differ at 13 amino acid residues throughout the peptide chain, and are expressed differently. Human $G H-N$ is expressed primarily in the pituitary, but also found in several other tissues, although to a smaller extent, and $h G H-V$ is expressed in the placenta during pregnancy [7]. In addition to the main form of hGH, several different variants of hGH has been identified, differing in charge and size $[8,9]$.

\section{Molecular Weight and Charge Variants}

$20 \mathrm{~K}$ is a hGH isoform produced in the pituitary by alternate splicing of the GH mRNA having a molecular weight of 20,000 daltons (20K) and lacking 15 amino acids in position 32 to 46 . The $20 \mathrm{~K}$ form of hGH comprises between 6 and $10 \%$ of the hGH present in the pituitary and was first described by Lewis et al. [10]. The $20 \mathrm{~K}$ variant has been shown to exert similar effects on growth in experimental animals [11], and metabolism in humans as the normal $22 \mathrm{~K}$ hGH [12], but has shown poor lactogenic activity. Several high molecular weight (big, big-big), and oligomeric variants of $\mathrm{hGH}$ and $20 \mathrm{~K}$ have been isolated, among them dimeric forms, both covalently and 
non-covalently bound variants [13]. High molecular weight variants of GH have been isolated from pituitaries and from cultures with pituitary cells, but also from plasma, thus, indicating a wide distribution of variant GH's secreted. The oligomeric variants of $\mathrm{GH}$ demonstrate a variable, but mainly decreased, biological activity compared to the monomeric forms $[14,15]$.

A number of charge isoforms of growth hormone have furthermore been isolated, mainly from pituitary extracts. These isoforms include deamidated and amino-acetylated variants [16]. Deamidation has been shown to occur at amino acid residues 137 and 152 [17]. Deamidation of the hGH molecule was shown to make it more prone to proteolytic cleavage, and two-chain variants of the hormone have been identified [18]. The biological action of the charge isomers were shown to exert similar growth-promoting and diabetogenic activity as native pituitary hGH in rodent models [19]. A glycosylated variant of hGH has also been isolated [20], but the bioactivity of this variant is still not fully elucidated.

\section{Placental GH, hGH-V}

Placental $\mathrm{GH}, \mathrm{hGH}-\mathrm{V}$, is a variant $\mathrm{GH}$ which is produced in the placenta during pregnancy. It differs from hGH-N in 13 amino acid residues, and has a higher isoelectric point. The hormone is composed of two variants, one of which is glycosylated and has a slightly higher molecular weight. In contrast to pituitary $\mathrm{GH}$, it is secreted in a non-pulsatile manner, and secretion rises continuously during the second and third trimester of pregnancy, simultaneously inhibiting pituitary GH secretion. The concentration of hGH-V falls immediately at the onset of labor, as well as at cesarean section. Placental GH is only detected in maternal blood, not in fetal circulation. Recent studies have further demonstrated the availability of placental GH in amniotic fluid [21]. The factors regulating the production of placental $\mathrm{GH}$ are merely unknown, but increased maternal glucose decrease secretion of placental GH [22]. The main function of hGH-V may be on placental development and nutrient availability to the fetus $[9,23,24]$.

\section{GROWTH HORMONE BIOSYNTHESIS}

The genes encoding human GH is found on chromosome 17 , and is part of a cluster of five genes, including the genes for the two GHs, $h G H-N, h G H-V$, and Chorionic somatomammotropin (CS or Placental Lactogen). The genes show a different pattern of tissue-specific expression in the anterior pituitary somatotrophs $(h G H-N)$ and in the placental syncytiotrophoblasts ( $h G H-V$ and $C S$ ) [25]. Further data have shown that GH is also expressed in other peripheral tissues, probably exerting auto-or paracrine functions in the local environment [26].

The expression of the $h G H-N$ gene is controlled by transcription factors, among which Pit- 1 plays a central role [27]. Inactivation or lack of functional Pit-1 expression in both mice and man inhibits the differentiation and proliferation of the pituitary cells [28]. Several studies have revealed that Pit-1 complexes at DNaseI hypersensitive sites (HS), specifically at the HS-I site, establishing a acetylated histone domain which potentiates $h G H-N$ transcription [2931]. HS-I is located within the locus control region (LCR) 5, to the $h G H-N$ gene, and was recently shown to be crucial for establishing a domain of non-coding polymerase II (PolII) transcription, which is linked with chromatin organization of the $h G H-N$ locus, thus, constituting a robust pathway for gene activation [32].

However, expression and binding of Pit-1 is not enough for GH transcription, as other transcription factors are also required and cooperate with Pit-1. Such factors are the Sp1 protein, which also binds the GH promoter, assisting Pit-1 to bind to its site and $Z n-15$ which seem to function synergistically with Pit- 1 in order to activate the GH promoter [33]. Other transcription factors involved in the regulation of $\mathrm{GH}$ expression are cAMP response element binding protein (CREB) [34], the activator protein (AP2) [35] and possibly the upstream stimulatory factor (USF) [36]. Studies to determine interactions between specific transcription factors and GH mRNA abundance revealed a significant correlation for Pit-1, Prop- 1 and Zn-16, all of which were significantly decreased (or not detected) in hypopituitary (Ames or Snell dwarf) mice strains, but increased to approximately $200 \%$ in mice overproducing $\mathrm{GH}$ [37]. Prop-1 has been demonstrated to activate Pit-1 expression in the pituitary, but was also suggested to have other (functional) roles since low levels of Prop-1 mRNA were detected in normal mouse pituitaries. The exact function of $\mathrm{Zn-16}$ is not fully elucidated, but the significant correlation with eg. GH mRNA may predict a transcription factor which synergize with somatotrophic Pit-1. Factors that are negatively involved in the regulation of $\mathrm{GH}$ expression is the zinc finger Ikaros (Ikl) which deacetylates histone 3 residues in the GH promoter and limits the access of Pit-1, thus limiting GH expression [38], and Thyroid transcription factor1 (TTF-1), which binds to the promoter region of the GH gene and inhibit transcription [39]. DNA methylation is another (negative) regulator of GH gene transcription $[40$, 41].

Although Pit-1 is mainly expressed in the pituitary cells, it has also been demonstrated in extrapituitary tissues, including lymphoid tissue and haemapoietic cells but also mammary gland cells (normal and breast cancer cells). Recent data indicate that expression of Pit-1 in the mammary gland regulates local GH expression and may be involved in mammary development and possibly breast disorders [42].

$\mathrm{GH}$ is expressed in the brain, in areas different from the pituitary, such as the hippocampus, cortex, caudate nucleus and retinal areas [43]. Expression has been shown to increase following injury [44] and also in response to learning [45].

\section{REGULATION OF GROWTH HORMONE SECRETION}

Growth hormone has for long been considered a classical hormone, exerting endocrine functions. However, it is now accepted, that GH in addition to its expression in the anterior pituitary, is also produced peripherally and exerts both autoand paracrine actions [26]. Variants of growth hormone, such as the placental GH (hGH-V), are produced locally in 
the syncytiotrophoblasts, and exert its effects both in paracrine and endocrine manners.

It is well established that pituitary growth hormone is secreted in a pulsatile manner from the pituitary. The secretory pattern of $\mathrm{GH}$ was initially elucidated in rats, demonstrating a distinct difference in GH secretion between males, with low trough levels and high amplitude peaks, and females, showing higher basal levels (troughs) and less pronounced peaks [46]. The pulsatility of GH in male rats is very consistent, with peaks appearing approximately every $3^{\text {rd }}$ hour, whereas the female pattern is less regular. In addition, the difference in $\mathrm{GH}$ secretion in males and females, led to the physiological explanation of the corresponding sexual dimorphism resulting from the difference in GH secretory patterns, demonstrating significant differences in linear growth and the hepatic steroid metabolism $[47,48]$. The male pulsatile GH pattern, was shown the most efficient for longitudinal growth [49]. In humans, the diurnal secretory pattern of $\mathrm{hGH}$ is fully developed after puberty, demonstrating a major peak at late night/early morning which is associated with the REM-sleep, and a number of peaks during the light hours of the day, generally varying between 3 and 6 peaks per day, but with quite large individual difference $[50,51]$. Growth hormone secretion is mainly regulated by the concerted action of the hypothalamic factors, Growth hormone releasing hormone (GHRH) [52] and somatostatin (somatotropin releasing inhibiting factor; SRIF) [53] both produced in the hypothalamus and reaching the pituitary via the pituitaryportal system [54-56]. Further studies have revealed that SRIF regulates the magnitude of the troughs of $\mathrm{GH}$ as well as the amplitude of the peaks, whereas GHRH function as the main regulator of the pulsatile pattern $[57,58]$.

It is well known that growth hormone can regulate its own secretion. Several studies in animals and humans have shown that GH inhibits its own secretion. This has been demonstrated in humans and rodents during exogenous administration of $\mathrm{GH}$ or $20 \mathrm{~K} \mathrm{hGH} \mathrm{[59-61],} \mathrm{and} \mathrm{during}$ pregnancy, when maternal circulating levels of placental GH increases, and the pulsatile secretion of pituitary $\mathrm{GH}$ disappeared [62], The mechanism behind the inhibition may be two-fold, depending on whether it is a short term inhibitory loop or if the inhibition is longer term. The short term inhibition is most likely due to $\mathrm{GH}$-induced stimulation of SRIF release and inhibition of GHRH secretion [63, 64]. However, in the long term feedback situation, the inhibition of GH secretion is most likely due to feedback inhibition by IGF-I. Infusion of IGF-I induced a decrease in total plasma levels of $\mathrm{GH}$ by $50-80 \%$ of initial levels in both males and females, and more or less abolished the pulsatile secretion [57]. Interestingly, IGF-I infusion suppressed GHRH induced GH release in males, but not in females, suggesting a sexually dimorphic effect. Thus, the results suggest that increased plasma levels of IGF-I suppress GH secretion at the hypothalamic level in females, whereas in males suppression may be either at the pituitary or hypothalamic levels. Others have proposed that in the hypothalamus, mainly locally produced IGF-I is responsible for the feedback inhibitory actions on GH release, eg by enhancing
SRIF release. Available data further demonstrated the lack of effects on the expression of hypothalamic GHRH and SRIF in rodents depleted of IGF-I produced in the liver [65]. In vitro studies, using pituitary cells, revealed a significant inhibitory action on GH secretion of IGF-I in all species tested. Based on current knowledge, it seems as if most of the IGF-I feedback regulation on GH secretion is maintained via the pituitary.

The gastric peptide ghrelin has been identified as a stimulator of $\mathrm{GH}$ release. Ghrelin mRNA was detected primarily in the stomach, but has also been demonstrated in other cells, including the hypothalamus [66], and stimulates the secretion of $\mathrm{GH}$, although several other functions especially affecting food intake and metabolism have been attributed to this factor. Recent data suggests that the presence of hypothalamic GHRH is needed for the full action as demonstrated by the use of synthetic ghrelin analogues [57]. Others have proposed that, in spite of only limited endogenous regulatory functional effects on $\mathrm{GH}$ secretion, ghrelin may act as link between metabolic status and growth [67].

Other studies have demonstrated the importance of dopamine, cathecholamines and cholinergic factors in the regulation of pituitary $\mathrm{GH}$ secretion, which regulate $\mathrm{GH}$ via GHRH and SRIF, respectively. Furthermore, glucocorticoids inhibit GH secretion, probably via increased expression of SRIF [68]. Sex hormones affect the production of GH, acting both at hypothalamic, pituitary and peripheral levels. They are important factors for the increased $\mathrm{GH}$ secretion observed during puberty (see below) but also later in life. Both estrogen and testosterone increase $\mathrm{GH}$ secretion in humans by amplifying secretory burst mass and reduce the orderliness of the GH secretion [69]. Estrogen affects GH secretion mainly by interacting with the estrogen receptor (ER) ER $\alpha$, expressed in the GHRH neurons and in GHsecreting pituitary cells. It has been proposed that the stimulatory effects of estrogen on GH secretion is mediated via the release of GHRH and/or by enhancing the sensitivity to ghrelin released from the hypothalamus [70].

Further endogenous and exogenous factors that influence the secretion of GH have been identified. Examples of such factors are arginine, insulin (hypoglycemia), clonidine, levodopa and pyridostigmine, some of which have been used clinically to identify potential pituitary insufficiency. Recent studies have revealed that the GH response to all of the above factors is inhibited by GHRH receptor antagonists, thus, indicating that the mechanism by which $\mathrm{GH}$ is secreted in response to these stimuli, is via GHRH [71].

Pituitary secretion of $\mathrm{GH}$ is significantly increased in situations of dietary restriction and fasting. Ho et al. [72] reported that a 5-day fast in normal men resulted in significantly increased pulse frequency as well as pulse amplitude. The mechanism behind the increased secretion may be explained by the decreased expression and secretion of IGF-I in response to the fasting, thus, limiting the feedback inhibitory effect on pituitary GH secretion (see above). In addition, leptin, an anorexigenic peptide expressed in adipocytes as well as in the pituitary and other 
areas of the brain, has been identified as an important modulator of GH secretion. Leptin exerts differential effects on GH secretion, depending on whether the impact is shortterm or long-term [73]. Short term effects of leptin increase GH secretion, mainly by increase in GHRH and decrease in SRIF expression, whereas long-term effects significantly decrease GH secretion, probably due to a decreased response to GHRH. In obese subjects, GH secretion is reduced both in animals and humans, and GH responsiveness is decreased. Interestingly, the pulsatile secretion was decreased in obese rats [74], whereas in humans total daily GH secretion was decreased, but with intact pulsatility [75]. Leptin plasma concentrations are constantly increased, which may be part of the explanation to the decreased GH secretion in obesity [76].

GH synthesis and secretion exhibit major changes with age. The pulsatile secretion is markedly increased in early infanthood, possibly due to low circulating IGF-I levels, as GH sensitivity is low immediately after birth. A major increase in the total secretion of human GH in adolescents is observed at the growth spurt during puberty, which is reflected both in increased peak number and peak amplitude [69]. Pubertal increases in GH are largely associated with changes in the levels of sex hormones. Recent data has revealed that estrogen affects the increase in $\mathrm{GH}$ secretion mainly by increasing the irregularity in pulsatility and lowering total and free IGF-I, whereas testosterone rather increases basal GH secretion and IGF-I concentrations, thus, relieving the negative feedback (by IGF-I) on the GH secretion [69]. Correlation analysis showed that (IGF-I and) GH secretory pulse mass directly varied with serum testosterone concentrations [77]. The total amount of hGH secreted daily differs between males and females, being approximately twice as high in females as in males.

GH secretion declines with age in all mammals studied, starting already at early adulthood [78, 79]. The mechanism by which $\mathrm{GH}$ is decreased is primarily due to reduction in hypothalamic GHRH secretion, but depletion in sex steroids may also be part of the puzzle.

Several studies, especially in rodents, have recently shown that decreased GH secretion and concomitant reduction in circulating IGF-I is associated with increased longevity. Possible explanations include metabolic changes, e.g. increased insulin sensitivity, with subsequent modulation of glucose and fat metabolism, and decreased susceptibility to stress and carcinogenesis [80]. The age related changes of the GH/IGF-I axis will be discussed in further detail in Chapter 11 of this volume.

\section{GROWTH HORMONE BINDING PROTEINS}

The biological effects of growth hormone are mediated via the binding of GH to a specific membrane receptor. The GH receptor (GHR) is single-chain, trans-membrane Type I cytokine receptor, expressed in most tissues. It is expressed as a monomer, but for activation by $\mathrm{GH}$, two receptors form a dimer complexing with one $\mathrm{GH}$ molecule [81]. Intracellular signaling is mediated via the JAK2/Stat5a and Stat5b pathway, but increasing evidence has shown that activation via the Src tyrosine kinase family and subsequent activation of extracellular regulated kinases may be an alternate pathway [82]. Nuclear accumulation of GHRs have been reported, especially in different types of cancers.

In humans, slightly less than $50 \%$ of GH is bound to high $\mathrm{mw}$ carrier proteins in the circulation. To date, two $\mathrm{GH}$ binding proteins have been identified, one of which has high affinity and comprises the extracellular domain of the $\mathrm{GH}$ receptor and another with low affinity, which has been identified as a $\alpha-2$ macroglobulin, which may be of less importance [83]. The high-affinity GHBP is mainly produced by proteolytic cleavage of the receptor through ectodomain shedding, although in some species (rats, mice) alternative splicing have been shown. High affinity GHBPs have been demonstrated in many species. However, the function of GHBP is not fully elucidated, but it is likely to be involved in modulating the availability and activity of circulating GH. Results reveal that GHBP blocks binding of GH to the GHR, and thus, inhibit the subsequent biological activity of GH. On the other hand, GHBP significantly prolong the half life of GH in plasma, and it has been shown that GHBP may even improve the activity of GH in some cases [84]. A comprehensive summary of the current knowledge of GH receptors and GHBP is found in Chapter 2 of this volume.

In the brain, GH receptors/GHBP have been demonstrated in mammals in several areas, such as the hypothalamus, hippocampus and spinal cord, and in neuronal as well as non-neuronal cells $[44,85]$. It is interesting to note that GHR/GHBPs are to a great extent located in areas involved in neurogenesis [85]. A higher density of GHR/GHBP is generally observed during fetal development and early postnatal life. In man, the highest density of GH binding has been found in the choroid plexus [86, 87], suggesting that $\mathrm{GH}$ is transported across the blood-brainbarrier [88]. In humans, the concentration of GH in the CSF has been shown to increase after exogenously administered GH in patients with GH deficiency and high levels of GH have been measured in patients with acromegaly [89].

\section{INSULIN-LIKE GROWTH FACTOR-I (IGF-I)}

Initially, IGF-I was identified as the 'sulphation factor', as serum from normal individuals could stimulate in vitro incorporation of radioactive sulphate into embryonic chick or normal pig cartilage, but serum from hypophysectomized or growth hormone deficient individuals lacked this effect. No effect was observed when GH was added to the tissue in vitro, but serum from $\mathrm{GH}$ treated individuals was effective [90]. The factor was further identified as Somatomedin A [91] since it was 'mediating the effects of somatotropin'. Another name was Non-suppressible insulin-like activity (NSILA), as the factor could induce insulin-like activities but the effect was not inhibited by the addition of antibodies against insulin [92]. The final peptide sequence of human IGF-I was elucidated by Rinderknecht \& Humbel [93], who simultaneously published the final sequence for IGF-II, a peptide homologue to IGF-I, with slightly different properties. IGF-II, which seems to play an important role in fetal and cancer development, regulating proliferation, 
apoptosis and energy production, is not included in this review. IGF-I has a molecular weight of $7.5 \mathrm{kD}$, comprises 70 amino acids with three disulphide bridges. It is a structural homologue to pro-insulin, consisting of two domains connected via a C-peptide and an extended Edomain. There is a high homology in the IGF-I amino acid sequences between human and non-human species. Human, porcine, bovine and ovine IGF-Is have identical amino acid sequences, whereas rat and mouse IGF-Is exhibit $96 \%$ and $94 \%$ sequence homology, respectively [94]. IGF-I from further species have been sequenced and exhibit a high level of similarity with the human hormone, e.g. kangaroo (91\%), chicken (89\%), salmon $(80 \%)$ and barramundi $(77 \%)$ sequence homology. Also their affinity to IGF-I receptors and biological activity seem highly conserved [95].

Already from the early studies it was clear that liver was a major site for IGF production, but later investigations have confirmed the expression and secretion of IGF-I from many different sites and cell types, including the CNS [96, 97]. The expression of IGF-I is mainly modulated by GH, but also other factors are involved in the stimulation of expression and regulation of secretion of the peptide. IGF-I exerts its biological actions in auto-and paracrine manners but also in an endocrine fashion. It does not exhibit any diurnal variation.

\section{IGF-I BIOSYNTHESIS}

The gene for IGF-I, igf-1, is located on chromosome 12 and consists of 6 exons and 5 introns $[98,99]$. The major expression of the polypeptide is found in the liver in most species, but IGF-I is also expressed in almost all cells in the body. Transcription is initiated via two promoters, the major promoter (P1) which is active in all tissues and regulates IGF-I mRNAs containing exon 1, and the second promoter (P2) which regulates the transcription of IGF-I mRNA containing exon 2 , and is primarily expressed in the liver $[100,101]$. Recent data reveal that the exon 1 promoter contains four transcription initiation sites, and the exon 2 promoter has two sites. The two promoters are both found in mammals, whereas in non-mammalian vertebrates only a single promoter is identified in conjunction with exon 1 [102]. Both promoters are activated by GH, and it has been demonstrated that $\mathrm{GH}$ induces an alteration in the chromatin structure in the second intron with a single HS site (HS7) appearing prior to IGF-I gene transcription [103]. Further studies revealed two binding sites, with high and low affinity, for Signal transducer and activator of transcription (Stat) $5 \mathrm{~b}$ in the HS7 region in the mammalian IGF-I gene, and it has been shown that GH induces binding of Stat5b to this region immediately before initiation of IGF-I gene transcription from both promoters [104]. Further results supported the possibility of several Stat5b binding sites, and suggested that apparently redundant response elements may be able to amplify the GH activity for specific genes [105, 106]. Stat5b has also been identified as an important initiator of IGF-I gene transcription in humans, since patients with short stature have been shown to have point mutations in the Stat5b gene $[107,108]$.
It has recently been demonstrated that the igf- 1 gene can generate several transcripts due to multiple transcription initiation sites, alternate splicing especially at the C-terminal, and different polyadenylation sites. All IGF-I mRNA comprises exons 3 and 4, but splice variants containing exon 4 spliced to exon 6 (designated IGF-IEa) or to exons 5 and 6 (designated IGF-IEb in rodents, but IGF-IEc in humans), respectively, have been observed. It has been proposed that the IGF-IEb mRNA is increased after skeletal muscle injury, with a possible subsequent role in muscle remodeling, and named mechano-growth factor (MGF) [109]. No corresponding peptide has yet been identified in vivo, and further work is needed to elucidate the possible role and bioactivity of the different splice variants.

IGF-I is expressed in the CNS $[87,110]$ as well as in the peripheral nervous system [111]. Within the CNS, IGF-I expression is observed in several regions, being highest during development, but post-natally the major areas in which IGF-I is expressed are the olfactory bulb, hippocampus, and the Purkinje cells in the cerebellum [112]. In adult mammals, expression is generally lower, and further restricted predominantly to the brain stem and cerebellum [110]. Peripherally, IGF-I has been detected in the ventral horn, sympathetic and dorsal root ganglia, axons and Schwann cells of the sciatic nerve in adult rats $[111,113$, 114].

In both fetal and adult brain tissue, a truncated form of IGF-I lacking the $3 \mathrm{~N}$-terminal amino acids, has been demonstrated, most likely being a result of posttranslational modifications [115]. Truncated IGF-I (des-N-(1-3)-IGF-I) has further been found in peripheral tissues, and in colostrum. The truncated variant binds only weakly to the IGFBPs, thus, making the peptide readily available for biological action at the receptor site. The amino-terminal tri-peptide, consisting of amino acids Gly-Pro-Glu (GPE), has been identified in human brain as well as in peripheral tissues, and is formed after cleavage by acid proteases. The tri-peptide does not interact with IGF-I receptors or IGFBPs but seem to exert neuroprotective activities via the NMDA receptors [116]. GPE may activate NMDA receptors by binding to both glutamate and glycine binding sites, but the precise mechanism of action is not yet fully elucidated. However, results indicate that GPE has comparable antagonistic NMDA effects to the well-known NMDA antagonist AP-5 and that MK801, another NMDA antagonist, blocks the effects of GPE on glial cell proliferation.

IGF-I expression is increased in response to injury. Elevated immunoreactivity has been demonstrated in several tissues, such as peripheral nerves, skeletal muscle and endothelial cells in response to injury in rats [117-119]. A marked increase in IGF-I expression has also been shown in brain after hypoxic-ischemic insults [120], suggesting that locally produced IGF-I acting in an autocrine/paracrine manner is important for local regenerative processes.

\section{REGULATION OF IGF-I SECRETION}

The liver is the main production site for plasma IGF-I, but most cells in the body have the possibility of expressing and producing IGF-I $[96,97]$. The expression of IGF-I is 
regulated by hormones, of which GH plays a major role, oncogenes and other growth factors. Another major factor influencing plasma levels of IGF-I is nutrition.

Growth hormone induces transcription of the IGF-I gene potently and rapidly, especially in the liver. The major mechanism, by which GH induces IGF-I production, appears to be by binding to the GH receptor, activation of the JAK2 pathway and phosphorylation of Stat5b [121]. Although GH is a major regulator of IGF-I gene expression, peripheral synthesis of the peptide is also regulated by other hormones and factors. In osteoblasts, the main regulator of IGF-I expression is PTH, which initiates IGF-I synthesis via cAMP $[122,123]$. Estrogens are known to increase the expression of IGF-I in different brain regions as well as in peripheral cells. A recent study revealed IGF-I production was regulated via the $\mathrm{E} 2 \alpha$ receptor in mouse fallopian tubes [124]. Furthermore, Venken et al. [125] showed that estrogen can upregulate hepatic IGF-I synthesis independently of $\mathrm{GH}$, and thereby stimulating pubertal skeletal growth. Conflicting results regarding the effects of glucocorticoids on IGF-I expression are available, and both increased and decreased IGF-I synthesis has been reported. Thyroid hormones, such as $\mathrm{T}_{3}$ and $\mathrm{TSH}$, enhance the production of IGF-I, and significant decreases of IGF-I expression in different brain regions have been demonstrated after experimental induction of hypothyroidism in fetal mice [126]. PDGF and FGF both increase expression and synthesis of IGF-I.

Nutritional status affects IGF-I plasma levels significantly, and energy depletion or protein starvation lower circulating IGF-I levels. The changes in IGF-I secretion during starvation is independent of changes in pituitary GH secretion, but is likely due to decreased expression and signaling from hepatic $\mathrm{GH}$ receptors. However, changes in the pharmacokinetics of IGF-I and IGFBPs have also been observed [127].

Plasma levels of IGF-I are low at birth, slowly rises during childhood, peak just prior to puberty reaching adult levels, and further decreases with increasing age [128]. Postnatally, the age dependent changes in both plasma and tissue IGF-I concentrations are mainly dependent on the agerelated changes in GH secretion and GH sensitivity [129], but age-related changes in other hormones, e.g. sex steroids, also impact the synthesis. Fetal plasma levels of IGF-I are generally quite low but raise during the last part of the third trimester. Fetal concentrations of IGF-I are independent of pituitary GH secretion, but associated with placental GH production [130]. Further details of the age related changes of the GH/IGF-I axis will be discussed in Chapter 11 of this volume.

\section{IGF-I BINDING PROTEINS}

The majority of IGF-I in plasma is bound to larger carrier proteins. Six binding proteins with high affinity for IGF-I (IGFBP-1 to -6) have been identified and documented in mammals. The binding proteins are modulators of IGF-I activity, acting both as inhibitors and potentiators, as well as a reservoir of IGF-I in plasma. The IGFBPs are subject to proteolysis by different proteases, which reduce the affinity for IGF-I and modulate the availability of the peptide at the receptor level [131]. In addition, they do exert biological actions on their own [132]. IGFBPs are expressed at different levels in many tissues, including the brain, the only exception being IGFBP-1, which does not exhibit CNS expression.

IGFBP-1 and IGFBP-2 both contain an Arg-Gly-Asp (RGD) integrin binding site [133, 134], which likely is important both for enhancing the bioactivity of IGF-I at the cellular level and actions independent of IGF-I [135]. IGFBP-1 is expressed, in addition to the liver, also in the kidney as well as in other tissues such as the endometrium. It circulates in plasma, is mainly regulated by insulin, and either enhance or inhibit IGF-I actions, depending on its state of phosphorylation [132]. IGFBP-2 is expressed in high amount in several tissues and is the most prevalent IGFBP in the nervous system (CNS and peripherally), with the highest expression observed in embryonic tissues and during fetal development in areas of remodelling [136, 137]. In spite of decreased secretion after birth, IGFBP-2 is present in both plasma and CSF throughout life. The main function seems to be inhibition of the IGF-I action [138], although in the brain, IGFBP-2 may act as a facilitator for IGF-I activity [139, 140].

IGFBP-3 is produced in the liver, predominantly expressed in non-parenchymal cells [141], and function as the main carrier of IGF-I in the circulation, prolonging the half-life of the peptide. It is associated with a large glycoprotein, the acid-labile subunit (ALS), expressed in hepatocytes [141], and IGF-I to form a ternary complex [142], and function as a reservoir of IGF-I. However, IGFBP-3 is not confined to plasma, its mRNA has been identified in several tissues apart from the liver, and it has been shown to exert effects locally at a cellular level modulating IGF-I activity, but also exerting IGF-I independent actions [132]. In the CNS, IGBP-3 is expressed only at low levels, mainly in non-neuronal but possibly also in neuronal cells, as shown in vitro after GH treatment [143, 144].

IGFBP-4 is expressed in the liver, from which plasma IGFBP-4 is derived, but expression has been shown in several tissues including osteoblasts, fibroblasts, cells in reproductive organs and embryonic cells [145]. In the CNS, only very low levels of IGFBP-4 have been shown, in different brain cells during embryonic development, and postnally mainly in the hippocampus and olfactory bulb [146]. Results from in vitro and in vivo studies demonstrate mainly an inhibitory action of IGFBP-4 on IGF-I activity [145].

IGFBP-5 is abundant in plasma, and the second most important carrier of circulating IGF-I. Similar to IGFBP-3, IGFBP-5 forms a ternary complex with ALS. IGFBP-5 is to a great extent expressed in the same tissues as IGFBP-3. In the CNS, IGFBP-5 is highly expressed during embryonic development of the brain as shown in rats [147, 148], but is also shown to be an important player in bone development [149] and in tumor biology [150]. A potentiating effect on 
IGF-I activity has been demonstrated by IGFBP-5, and interestingly, IGF-I itself increases the expression of IGFBP$5[132,147,151]$. Both IGFBP-3 and IGFBP-5 have further been shown to bind to nuclear sites and exert IGF-I independent actions $[132,152,153]$.

IGFBP-6 is mainly expressed peripherally, and is expressed within the CNS at very low levels. The IGFBP-6 has a preferential binding for the IGF-I homologue IGF-II, and seems mainly to function as inhibitor of IGF-II action in different IGF-II dependent cancers [154].

\section{FUTURE STRATEGIES}

Most of the data available on the expression and actions of $\mathrm{GH}$ is based on its secretion from the anterior pituitary and endocrine function. Similarly, data on the expression, secretion and regulation of IGF-I is based mainly on results from peripheral organs, the liver being the major organ for the production of plasma IGF-I. However, during the last decades an increasing amount of data on the biosynthesis and function of GH and IGF-I in the CNS have emerged. It has been demonstrated that $\mathrm{GH}$ is expressed locally in certain areas of the brain, apart from the pituitary, and exert specific actions either directly or via the induction of locally produced IGF-I. IGF-I is expressed in several CNS areas, acting mainly in an autocrine and/or paracrine manner. Both hormones have furthermore been shown to pass the bloodbrain-barrier, therefore, also peripheral changes in $\mathrm{GH}$ and IGF-I concentrations may significantly influence the brain. The function of GH and IGF-I within the CNS include important effects on energy metabolism, neurogenesis, neuroprotection, regeneration, cognition and mood. However, detailed studies on the specific regulation of expression and synthesis of GH and IGF-I, as well as their receptors, in certain areas and cell types in the CNS will further elucidate the influence and potential therapeutic use of these peptides in brain injuries, Alzheimer's disease, learning deficiencies and old age. This is addressed and further discussed in later chapters of this volume.

\section{CONFLICT OF INTEREST}

The author is an employee of Astrazeneca.

\section{ACKNOWLEDGEMENT}

Declared none.

\section{REFERENCES}

[1] Crowe SI, Cushing H, Homans J. Experimental hypophysectomy. Bull Johns Hopkins Hosp 1910; 21: 127-60.

[2] Evans HM, Long JA. The effect of the anterior lobe of the hypophysis administered intraperitoneally upon growth, maturity and oestrus cycles of the rat. Anat Record (Abstract) 1921; 21: 61

[3] Evans HM. The function of the anterior hypophysis. The Harvey Lecture Series. New York: Academic Press 1924.

[4] Li CH, Papkoff H. Preparation and proteins of growth hormone from human and monkey pituitary glands. Science 1956; 124: 1293-94.

[5] Li CH, Dixon JS. Human pituitary growth hormone. 32. The primary structure of the hormone: revision. Arch Biochem Biophys 1971; 146: 233-6.

[6] Seeburg PH. The human growth hormone gene family: nucleotide sequences show recent divergence and predict a new polypeptide hormone. DNA 1982; 1: 239-49.
[7] Liebhaber SA, Urbansk M, Ray J, et al. Characterization and histological localization of human growth hormone-variant gene expression in the placenta. J Clin Invest 1989; 83: 1985-91.

[8] Baumann G. Growth hormone heterogeneity: Genes, isohormones, variants and binding proteins. Endocr Rev 1991; 12: 424-49.

[9] Baumann GP. Growth hormone isoforms. Growth Horm IGF Res 2009; 19: 333-40.

[10] Lewis UJ, Dunn JT, Bonewald LF, et al. A naturally occurring variant of human growth hormone. J Biol Chem 1978; 253: 267987.

[11] Ishikawa M, Tachibana $\mathrm{T}$, Kamioka $\mathrm{T}$, et al. Comparison of the somatogenic action of $20 \mathrm{kDa}$ and $22 \mathrm{kDa}$-human growth hormones in spontaneous dwarf rats. Growth Horm IGF Res 2000; 10: $199-206$

[12] Hayakawa M, Shimazaki Y, Tsushima T, et al. Metabolic effects of 20-kilodalton human growth hormone (20K-hGH) for adults with growth hormone deficiency: Results of an exploratory uncontrolled multicenter clinical trial of 20K-hGH. J Clin Endocrinol Metab 2004; 89: 1562-71.

[13] Brostedt P, Roos P. Isolation of dimeric forms of human pituitary growth hormone. Prep Biochem 1989; 19: 217-29.

[14] Yang N, Langenheim JF, Wang X, et al. Activation of growth hormone receptors by growth hormone and growth hormone antagonist dimers: insights into receptor triggering. Mol Endocrinol 2008; 22: 978-88.

[15] Gorden P, Lesniak MA, Hendricks CM, et al. "Big" growth hormone components from human plasma: decreased reactivity demonstrated by radioreceptor assay. Science 1973; 182: 829-31.

[16] Lewis UJ, Singh RN, Bonewald LF, et al. Human growth hormone : additional members of the complex. Endocrinol 1979; 104: 125665 .

[17] Lewis UJ, Singh RN, Bonewald LF, et al. Altered proteolytic cleavage of human growth hormone as a result of deamidation. $\mathrm{J}$ Biol Chem 1981; 256: 11645-50.

[18] Lewis UJ, Singh RNP, Tutwiler GF, et al. Human growth hormone: A complex of proteins. Rec Progr Horm Res 1980; 36: 477-508.

[19] Skottner A, Forsman A, Skoog B, et al. Biological characterization of charge isomers of human growth hormone. Acta Endocrinol 1988; 118: 14-21.

[20] Haro LS, Lewis UJ, Garcia M, et al. Glycosylated human growth hormone (hGH): a novel $24 \mathrm{kDa}$ hGH-N variant. Biochem Biophys Res Commun 1996; 228: 549-56.

[21] Mittal P, Hassan SS, Esponoza J, et al. The effect of gestational age and labor on placental growth hormone in amniotic fluid. Growth Horm IGF-I Res 2008; 18: 174-9.

[22] De Jesus Romero-Prado MM, Barrera-Saldana HA, Castrilla-Diez JL. hGH-V gene expression and promoter activity under glucose and 5-azacytidine (5azaC) effects. Gene 2009; 452: 7-15.

[23] Alsat E, Guibourdenche J, Luton D, et al. Human placental growth hormone. Am J Obstet Gynecol 1997; 177: 1526-34.

[24] Alsat E, Guibourdenche J, Couturier A, et al. Physiological role of human placental growth hormone. Mol Cell Endocrinol 1998; 140: 121-7.

[25] Chen EY, Liao YC, Smith DH, et al. The human growth hormone locus: nucleotide sequence. Biol Evol Genom 1989; 4: 479-97.

[26] Harvey S, Hull KL. Growth hormone. A paracrine growth factor? Endocrine 1997; 7: 267-79.

[27] Simmons DM, Voss JW, Ingraham HA, et al. Pituitary cell phenotypes involve cell-specific Pit-1 mRNA translation and synergistic interactions with other classes of transcription factors. Genes Dev 1990; 4: 695-711.

[28] Li S, Crenshaw EB III, Rawson EJ, et al. Dwarf locus mutants lacking three pituitary cell types result from mutations in the POUdomain gene Pit-1. Nature 1990; 347: 528-33.

[29] Elefant F, Cooke NE, Liebhaber SA. Targeted recruitment of histone acetyltransferase activity to a locus control region. J Biol Chem 2000; 275: 13827-34.

[30] Shewchuk BM, Liebhaber SA, Cooke NE. Specification of a unique Pit-1 activity in the hGH locus control region. Proc Natl Acad Sci USA 2002; 99: 11784-9.

[31] Hogan KA, Jefferson HS, Karschner VA, et al. Expression of Pit-1 in nonsomatotrope cell lines induces human growth hormone locus control region histone modification and hGH-N transcription. J Mol Biol 2009; 390: 26-44. 
[32] Ho Y, Tadevosyan A, Liebhaber SA, et al. The juxtaposition of a promoter with a locus control region transcriptional domain activates gene expression. EMBO Rep 2008; 9: 891-8.

[33] Chan CB, Tse MCL, Cheng CHK. In: Nyberg, Eds. Regulation and mechanism of growth hormone and Insulin-like growth factor-I biosynthesis and secretion. USA: Academic Press 2006; pp. 7-23.

[34] Bertherat J. Nuclear effects of the cAMP pathway activation in somatotrophs. Horm Res 1997; 94: 138-45.

[35] Imagawa M, Chiu R, Karin M. Transcription factor AP-2 mediates induction by two differential signal-transduction pathways: protein kinase C and cAMP. Cell 1987; 51: 251-60.

[36] Pan WT, Liu QR, Bancroft C. Identification of a growth hormone gene promoter repressor element and its cognate double-and singlestranded DNA binding proteins. J Biol Chem 1990; 265: 7022-8.

[37] Wojtkiewics PW, Phelps CJ, Hurley DL. Transcript abundance in mouse pituitaries with altered growth hormone expression quantified by reverse transcriptase polymerase chain reaction implicates transcription factor Zinc-16 in gene regulation in vivo. Endocrine 2002; 18: 67-74.

[38] Ezzat S, Yu S, Asa SL. The zinc finger Ikaros transcription factor regulates pituitary growth hormone and prolactin gene expression through distinct effects ion chromatin accessibility. Mol Endocrinol 2005; 19: 1004-11.

[39] Lee NO, Son YJ, Kim JG, et al. TTF-1 regulates growth hormone and prolactin transcription in the anterior pituitary gland. Biochem Biophys Res Commun 2007; 362: 193-9.

[40] Strobl JS, Dannies PS, Thompson EB. Rat growth hormone gene expression is correlated with an unmethylated CGCG sequence near the transcription initiation site. Biochemistry 1986; 25: 36408 .

[41] Kumar V, Biswas DK. Dynamic state of site-specific DNA methylation concurrent to altered prolactin and growth hormone gene expression in the pituitary glands of pregnant and lactating rats. J Biol Chem 1988; 263: 12645-52.

[42] Gil-Puig C, Seoane S, Blanco M, et al. Pit-1 is expressed in normal and timorous human breast and regulates $\mathrm{GH}$ secretion and cell proliferation. Eur J Endocrinol 2005; 153: 335-44.

[43] Gossard F, Dihl F, Pelletier G, et al. In situ hybridization to rat brain and pituitary gland of growth hormone cDNA. Neurosci Lett 1987; 79: 251-6.

[44] Scheepens A, Möderscheim TAE, Gluckman PD. The role of growth hormone in neuronal development. Horm Res 2005; 64 (Suppl 3): 66-72.

[45] Donahue CP, Jensen RV, Ochiishi T, et al. Transcriptional profiling reveals regulated genes in the hippocampus during memory formation. Hippocampus 2002; 12: 821-33.

[46] Eden S. Age-and sex-related differences in episodic growth hormone secretion in the rat. Endocrinol 1979; 105: 555-60.

[47] Mode A, Gustafsson JA, Jansson JO, et al. Association of plasma level of growth hormone and sex differentiation of hepatic steroid metabolism in the rat. Endocrinol 1982; 111: 1692-7.

[48] Norstedt G, Palmiter R. Secretory rhythm of growth hormone regulates sexual differentiation of mouse liver. Cell 1984; 36: 80512 .

[49] Clark RG, Jansson JO, Isaksson O, et al. Intravenous growth hormone: growth responses to pattern infusions in hypophysectomized rats. J Endocrinol 1985; 104: 53-61.

[50] Finkelstein JW, Roffwarg HP, Boyar RM, et al. Age-related change in the twenty-four-hour spontaneous secretion of growth hormone. J Clin Endocrinol Metab 1972; 35: 665-70.

[51] Surya S, Symons K, Rothman E, et al. Complex rhythmicity of growth hormone secretion in humans. Pituitary 2006; 9: 121-5.

[52] Guillemin R, Brazeau P, Böhlen P, et al. Growth hormone releasing factor from a human pancreatic tumor that caused acromegaly. Science 1982; 218: 585-7.

[53] Brazeau P, Vale W, Burgus R, et al. Hypothalamic polypeptide that inhibits the secretion of immunoreactive pituitary growth hormone. Science 1973; 179: 77-9.

[54] Tannenbaum GS, Martin JB. Evidence for an endogenous ultradian rhythm governing growth hormone secretion in the rat. Endocrinol 1976; 98: 562-70.

[55] Plotsky PM, Vale W. Patterns of growth hormone-releasing factor and somatostatin secretion into the hypophysial-portal circulation of the rat. Science 1985; 230: 461-3.
[56] Muller EE, Locatelli V, Cocchi D. Neuroendocrine control of growth hormone secretion. Physiol Rev 1999; 79: 511-607.

[57] Goldenberg N, Barkan A. Factors regulating growth hormone secretion in humans. Endocrinol Metab Clin 2007; 36: 37-55.

[58] Gahete MD, Duran-Prado M, Luque RM, et al. Understanding the multifactorial control of growth hormone release by somatotropes. Trends Comp Endocrinol Neurobiol 2009; 1163: 137-53.

[59] Clark RG, Carlsson LM, Robinson ICAF. Growth hormone (GH) secretion in the conscious rat: Negative feedback of GH on its own release. J Endocrinol 1988; 119: 201-9.

[60] Leung KC, Howe C, Gui LY, et al. Physiological and pharmacological regulation of $20-\mathrm{kDa}$ growth hormone. Am J Physiol Endocrinol Metab 2002; 283: E836-43.

[61] Hashimoto Y, Kamioka T, Hosaka M, et al. Exogenous 20K growth hormone $(\mathrm{GH})$ suppresses endogenous $22 \mathrm{~K}$ GH secretion in normal men. J Clin Endocrinol Metab 2000; 85: 601-6.

[62] Frankenne F, Closset J, Gomez F, et al. The physiology of growth hormones (GHs) in pregnant women and partial characterization of the placental GH variant. J Clin Endocrinol Metab 1988; 66: 117180 .

[63] Chomczynski P, Downs TR, Frohman LA. Feedback regulation of growth hormone $(\mathrm{GH})$-releasing hormone gene expression by $\mathrm{GH}$ in rat hypothalamus. Mol Endocrinol 1988; 2: 236-41.

[64] Berelowitz M, Firestone SL, Frohman LA. Effects of growth hormone excess and deficiency of hypothalamic somatostatin content and release and on tissue somatostatin distribution. Endocrinol 1981; 109: 714-9.

[65] Wallenius K, Sjögren K, Peng XD, et al. Liver-derived IGF-I regulates $\mathrm{GH}$ secretion at the pituitary level in mice. Endocrinol 2001; 142: 4762-70

[66] De Vriese C, Delporte C. Ghrelin: a new peptide regulating growth hormone release and food intake. Int J Biochem Cell Biol 2008; 40: 1420-4.

[67] Dimaraki EV, Jaffe CE. Role of endogenous ghrelin in growth hormone secretion, appetite regulation and metabolism. Rev Endocr Metab Disord 2006; 7: 237-49.

[68] Giustina A, Wehernberg WB. The role of glucocorticoids in the regulation of growth hormone secretion. Mechanisms and clinical significance. Trends Endocrinol Metab 1992; 3: 306-11.

[69] Veldhuis JD, Roemmich JN, Richmond EJ, et al. Somatotropic and gonadotropic axes linkages in infancy, childhood and the pubertyadult transition. Endocr Rev 2006; 27: 101-40.

[70] Kok P, Paolo RC, Cosma M, et al. Estrogen supplementation selectively enhances hypothalamo-pituitary sensitivity to ghrelin in postmenopausal women. J Clin Endocrinol Metab 2008; 93: 40206.

[71] Jaffe CA, DeMott-Friberg R, Barkan AL. Endogenous growth hormone $(\mathrm{GH})$-releasing hormone is required for $\mathrm{GH}$ responses to pharmacological stimuli. J Clin Invest 1996; 97: 934-40.

[72] Ho KY, Veldhuis JD, Johnson ML, et al. Fasting enhances growth hormone secretion and amplifies the complex rhythms of growth hormone secretion in man. J Clin Invest 1988; 81: 968-75.

[73] Saleri R, Giustina A, Tamanini C, et al. Leptin stimulates growth hormone secretion via a direct pituitary effect combined with a decreased somatostatin tone in a median eminence-pituitary perifusion study. Neuroendocrinology 2004; 79: 221-8.

[74] Tannenbaum GS, Lapointe M, Gurd W, et al. Mechanisms of impaired growth hormone secretion in genetically obese Zucker rats: Roles of growth hormone releasing factor and somatostatin. Endocrinol 1990; 127: 3087-95.

[75] Veldhuis JD, Iranmanesh A, Ho KKY, et al. Dual effects in pulsatile growth hormone secretion and clearance subserve the hyposomatotropism of obesity in man. J Clin Endocrinol Metab 1991; 72: 51-9.

[76] Ostlund RE, Yang JW, Klein S, et al. Relation between plasma leptin concentration and body fat, gender, diet, age and metabolic covariates. J Clin Endocrinol Metab 1996; 81: 3909-13.

[77] Veldhuis JD, Roemmich JN, Rogol AD. Gender and sexual maturation-dependent contrasts in the neuroregulation of growth hormone secretion in prepubertal and late adolescent males and females - A general clinical research center-based study. J Clin Endocrinol Metab 2000; 85: 2385-94.

[78] Muller EE, Cella SG, DeGennaro Colonna V, et al. Aspects of the neuroendocrine control of growth hormone secretion in aging mammals. J Reprod Fertil Suppl 1993; 46: 99-114. 
[79] Veldhuis J. Aging and hormones of the hypothalamo-pituitary axis: Gonadotropic axis in men and somatotropic axes in men and women. Ageing Res Rev 2008; 7: 189-208.

[80] Berryman DE, Sandahl CJ, Johannsson G, et al. Role of GH/IGF-I axis in lifespan and health span: Lessons from animal models. Growth Horm IGF-I Res 2008; 18: 455-71.

[81] Brooks AJ, Wooh JW, Tunny KA, et al. Growth hormone receptor: mechanism of action. Int J Biochem Cell Biol 2007; 40: 1984-9.

[82] Ling L, Zhu T, Lobie PE. Src-CrkII-C3G-dependent activation of RapI switches growth hormone stimulated p44/42MAP kinase and JNK/SAPK activities. J Biol Chem 2003; 278: 27301-11.

[83] Baumann G. Growth hormone binding protein. The soluble growth hormone receptor. Minerva Endocrinol 2002; 27: 265-76.

[84] Fisker, S. Physiology and pathophysiology of growth-hormone binding protein: Methodological and clinical aspects. Growth Horm IGF-I Res 2006; 16: 1-28.

[85] Lobie PE, Garcia-Aragon J, Lincoln DT, et al. Localization and ontogeny of growth hormone receptor gene expression in the central nervous system. Brain Res Dev Brain Res 1993; 74: 225-33.

[86] Nyberg, F. Growth hormone in the brain: characteristics of specific brain targets for the hormone and their functional significance. Front Neuroendocrinol 2000; 21:330-48.

[87] Nyberg, F. The role of the somatotrophic axis in neuroprotection and neurogeneration of the addictive brain. Int Rev Neurobiol 2009; 88: 399-427.

[88] Pan W, Yu Y, Cain CM, et al. Permeation of growth hormone across the blood-brain barrier. Endocrinol 2005; 146: 4898-904.

[89] Coculescu M. Blood-brain barrier for human growth hormone and insulin-like growth factor-I. J Ped Endocrinol 1999; 12: 113-24.

[90] Salmon WD, Daughaday WH. A hormonally controlled serum factor which stimulates sulphate incorporation by cartilage in vitro. J Lab Clin Med 1957; 49: 825-36.

[91] Hall K. Human somatomedin: determination, occurrence, biological activity and purification. Acta Endocrinol 1972; 163 (Suppl): 7.

[92] Froesch ER, Burgi H, Ramseier EB, et al. Antibody suppressible and non-suppressible insulin-like activity in human serum and their physiological significance. J Clin Invest 1963; 42: 1816-34.

[93] Rinderknecht E, Humbel RE. The amino acid sequence of human insulin-like growth factor I and its structural homology with proinsulin. J Biol Chem 1978; 253: 2769-76.

[94] Humbel R. Review. Insulin-like growth factors I and II. Eur J Biochem 1990; 190: 445-62.

[95] Upton Z, Yandell CA, Degger BG, et al. Evolution of insulin-like growth factor-I (IGF-I) action: in vitro characterization of vertebrate IGF-I proteins. Comp Biochem Physiol B Biochem Mol Biol 1998; 121: 35-41.

[96] D'Ercole AJ, Stiles AD, Underwood LE. Tissue concentrations of somatomedin C: Further evidence for multiple sites of synthesis and paracrine or autocrine mechanisms of action. Proc Natl Acad Sci USA 1984; 81: 935-9.

[97] Andersson I, Billig H, Fryklund L, et al. Localization of IGF-I in adult rats. Immunohistochemical studies. Acta Physiol Scand 1986; 126: 311-2.

[98] Brissenden JE, Ullrich A, Francke U. Human chromosomal mapping of genes for insulin-like growth factors I and II and epidermal growth factor. Nature 1984; 310: 781-4.

[99] De Pagter-Holthuizen P, van Schaik FMA, Verduijn GM, et al. Organization of the human genes for insulin-like growth factors I and II. FEBS Lett 1986; 195: 179-84.

[100] Hall LJ, Kajimoto Y, Bichell D, et al. Functional analysis of the rat insulin-like growth factor I gene and identification of an IGF-I gene promoter. DNA Cell Biol 1992; 11: 301-13.

[101] Adamo ML, Ben-Hur H, Roberts CTJ, et al. Regulation of start site usage in the leader exons of the rat insulin-like growth factor -I gene by development, fasting and diabetes. Mol Endocrinol 1991; 5: 1677-86.

[102] Woelfle J, Chia DJ, Massart-Schlessinger MB, et al. Molecular physiology, pathology and regulation of the growth hormone/insulin-like growth factor-I system. Pediatr Nephrol 2005; 20: 295-302.

[103] Thomas MJ, Kikuchi K, Bichell DP, et al. Characterization of deoxyribonucleic acid-protein interactions at a growth hormoneinducible nuclease hypersensitivity site in the rat insulin-like growth factor-I gene. Endocrinol 1995; 136: 562-9.
[104] Rotwein P, Chia DJ. Gene regulation by growth hormone. Pediatr Nephrol 2010; 25: 651-8.

[105] Chia DJ, Ono M, Woefle J, et al. Characterization of distinct Stat5b binding sites that mediate growth hormone-stimulated IGF-I gene transcription. J Biol Chem 2003; 281: 3190-7.

[106] Eleswarapu S, Gu Z, Jiang H. Growth hormone regulation of insulin-like growth factor-I gene expression may be mediated by multiple distal signal transducer and activator of transcription 5 binding sites. Endocrinol 2008; 149: 2230-40.

[107] Kofoed EM, Hwa V, Little B, et al. Growth hormone insensitivity associated with a STAT5b mutation. N Engl J Med 2003; 349: $1139-47$.

[108] Rosenfeld RG, BelgoroskyA, Camacho-Hubner C, et al. Defects in growth hormone receptor signaling. Trends Endocrinol Metab 2007; 18: 134-41.

[109] Matheny RW, Nindl BC, Adamo ML. Minireview: mechanogrowth factor: A putative product of IGF-I gene expression involved in tissue repair and regeneration. Endocrinol 2010; 151: 865-75.

[110] Lobie PE, Zhu T, Garichem R, et al. Growth hormone, insulin-like growth factor I and the CNS: localization, function and mechanism of action. Growth Horm IGF-I 2000; Res Suppl B: S51-S56.

[111] Sullivan KA, Kim B, Feldman EL. Minireview: Insulin-like growth factors in the peripheral nervous system. Endocrinol 2008; 149: 5963-71.

[112] Anlar B, Sullivan KA, Feldman EL. Insulin-like growth factor-I and central nervous system development. Horm Metab Res 1999; 31: 120-5.

[113] Hansson HA, Rozell B, Skottner A. Rapid axoplasmic transport of insulin-like growth factor I in the sciatic nerve of adult rats. Cell Tissue Res 1987; 247: 241-7.

[114] Hansson HA, Nilsson A, Isgaard J, et al. Immunohistochemical localization of insulin-like growth factor $\mathrm{I}$ in the adult rat. Histochemistry 1988; 89: 403-10.

[115] Sara VR, Carlsson-Skwirut C, Drakenberg K, et al. The biological role of truncated insulin-like growth factor-I and the tripeptide GPE in the central nervous system. Ann NY Acad Sci 1993; 692: 18391.

[116] Guan J, Gluckman PD. IGF-I derived small neuropeptides and analogues: a novel strategy for the development of pharmaceuticals for neurological conditions. Br J Pharmacol 2009; 157: 881-91.

[117] Hansson HA, Dahlin LB, Danielsen N, et al. Evidence indicating trophic importance of IGF-I in regenerating peripheral nerves. Acta Physiol Scand 1986; 126: 609-14.

[118] Hansson HA, Jennsiche E, Skottner A. Regenerating endothelial cells express insulin-like growth factor I immunoreactivity after arterial injury. Cell Tissue Res 1987; 250: 499-505.

[119] Jennische E, Skottner A, Hansson HA. Satellite cells epress the trophic factor IGF-I in regenerating skeletal muscle. Acta Physiol Scand 1987; 129: 9-15.

[120] Beilharz EJ, Russo VC, Butler G, et al. Co-ordinated and cellular specific induction of the components of the IGF/IGFBP axis in the rat brain following hypoxic-ischemic injury. Brain Res Mol Brain Res 1998; 59: 119-34.

[121] Rosenfeld RG, Hwa V. The growth hormone cascade and its role in mammalian growth. Horm Res 2009; 71 (Suppl 2): 36-40.

[122] McCarthy TL, Centrella M, Canalis E. Cyclic AMP induces insulin-like growth factor I synthesis in osteoblast-enriched cultures. J Biol Chem 1990; 265: 15353-6.

[123] Giustina A, Mazziotti G, Canalis E. Growth hormone, insulin-like growth factors and the skeleton. Endocr Rev 2008; 29: 535-59.

[124] Shao R, Egecioglu E, Weijdegard B, et al. Dynamic regulation of estrogen receptor alpha isoform expression in the mouse fallopian tube; mechanistic insight tinto estrogen-dependent production and secretion of insulin-like growth factors. Am J Physiol Endocrinol Metab 2007; 293: E1430-42.

[125] Venken K, Schuit F, Van LL, et al. Growth without growth hormone receptor: estradiol is a major growth hrome-independent regulator of hepatic IGF-I synthesis. J Bone Mineral Res 2005; 20: 2138-49.

[126] Elder DA, Karayal AF, D'Ercole AJ, et al. Effects of hypothyroidism on insulin-like growth factor $-\mathrm{I}$ expression during brain development in mice. Neurosci Lett 2000; 293: 99-102.

[127] Thissen JP, Ketelslegers JM, Underwood LE. Nutritional regulation of the insulin-like growth factors. Endocr Rev 1994; 15: 80-101. 
[128] Hall K, Sara VR. Somatomedin levels in childhood, adolescence and adult life. Clin Endocrinol Metab 1984; 13: 91-112.

[129] Cohen P. Overview of the IGF-I system. Horm Res 2006; 65 (Suppl): 3-8

[130] Setia S, Sridhar MG. Changes in GH/IGF-I axis in intrauterine growth retardation: Consequences or fetal programming? Horm Metab Res 2009; 41: 791-8.

[131] Bunn RC, Fowlkes JL. Insulin-like growth factor binding protein proteolysis. Trends Endocrinol Metab 2003; 14: 176-81.

[132] Firth SM, Baxter RC. Cellular action of the Insulin-like growth factor binding proteins. Endocr Rev 2002; 23: 824-54.

[133] Jones IJ, Gockerman A, Busby WH Jr, et al. Insulin-like growth factor binding protein 1 stimulates cell migration and binds to the alpha 5 beta 1 integrin by means of its Arg-Gly-Asp sequence. Proc Natl Acad Sci 1993; 90: 10553-7.

[134] Schutt BS, Langkamp M, Rauschnabel U, et al. Integrin-mediated action of insulin-like growth factor binding protein-2 in tumor cells. J Mol Endocrinol 2004; 32: 859-68.

[135] Wheatcroft SB, Kearney MT. IGF-dependent and IGF-independent actions of IGF-binding protein-1 and -2: implications for metabolic homeostasis. Trends Endocrinol Metab 2009; 20: 153-62.

[136] Sullivan KA, Feldman EL. Immunohistochemical localization of insulin-like growth factor II (IGF-II) and IGF-binding protein-2 during development in the rat brain. Endocrinol 1994; 135: 540-7.

[137] Chesik D, De Keyser J, Wilczak N. Insulin-like growth factor binding protein-2 as a regulator of IGF actions in the CNS: Implications in multple sclerosis. Cytokine Growth Factor Rev 2007; 18: 267-78

[138] Hoeflich A, Wu M, Mohan S, et al. Overexpression of insulin-like growth factor-binding protein-2 in transgenic mice reduces postnatal body weight gain. Endocrinol 1999; 140: 5488-96.

[139] Brooker GJ, Kalloniatis M, Russo VC, et al. Endogenous IGF-I regulates the neuronal differentiation of adult stem cells. J Neurosci Res 2000; 59: 332-41.

[140] Guan J, Williams CE, Skinner SJ, et al. The effects of insulin-like growth factor (IGF)-I, IGF-2 and des-IGF-I on neuronal loss after hypoxic-ischaemic brain injury in adult rats: Evidence for a role for IGF binding proteins. Endocrinol 1996; 137: 893-8.

[141] Scharf JG, Ramadori G, BraulkeT, et al. Cellular localization and hormonal regulation of biosynthesis of inlulin-like growth factor binding proteins and of the acid-labile subunit within rat liver. Prog Growth Factor Res 1995; 6: 175-80.
[142] Baxter RC, Martin JL, Beniac VA. High molecular weight insulinlike growth factor binding protein complex. Purification and properties of the acid-labile subunit from human serum. J Biol Chem 1989; 264: 11843-8.

[143] Russo VC, Werther GA. In: Nyberg, Ed. Growth hormone and insulin-like growth factors in the central nervous system: Localization in mammalian species. USA: Academic Press 2006; pp. 81-90.

[144] Ajo R, Cacicedo L, Navarro C, et al. Growth hormone action on proliferation and differentiation of cerebral cortical cells from fetal rat. Endocrinol 2003; 144: 1086-97.

[145] Mazerbourg S, Callbaut I, Zapf J, et al. Update on IGFBP-4: Regulation of IGFBP-4 levels and functions, in vitro and in vivo. Growth Horm IGF Res 2004; 14: 71-84

[146] Chernausek SD, Murray MA, Cheung PT. Expression of insulinlike growth factor binding protein-4 (IGFBP-4) by rat neural cells comparison to other IGFBPs. Reg Peptides 1993; 48: 123-32.

[147] Ye P, D'Ercole J. Insulin-like growth factor I (IGF-I) regulates IGF binding protein-5 gene expression in the brain. Endocrinol 1998; 139: 65-71

[148] Bondy CA, Lee WH. Patterns of insulin-like growth factor and IGF receptor gene expression in the brain. Functional implications. Ann NY Acad Sci 1993; 692; 33-43.

[149] Mukherjee A, Rotwein, P. Insulin-like growth factor binding protein-5 in osteogenesis: facilitator or inhibitor? Growth Horm IGF Res 2007; 17: 179-85.

[150] Beattie J, Allan GJ, Lochrie JD, et al. Insulin-like growth factorbinding protein-5 (IGFBP-5): a critical member of the IGF-I axis. Biochem J 2006; 395: 1-19.

[151] Duan C, Clemmons DR. Differential expression and biological effects on insulin-like growth factor-binding protain-4 and -5 in vascular smooth muscle cells. J Biol Chem 1998; 273: 16836-42.

[152] Schedlich LJ, Le Page SL, Firth SM, et al. Nuclear import of insulin-like growth factor-binding protein- 3 and -5 is mediated by the importin beta subunit. J Biol Chem 2000; 275: 23462-70.

[153] Santer FR, Bacher N, Moser B, et al. Nuclear insulin-like growth factor binding protein-3 induces apoptosis and is targeted to ubiquitin/proteasome-dependent proteolysis. Cancer Res 2006; 66 : 3024-33.

[154] Bach LA. IGFBP-6 five years on: not so 'forgotten'? Growth Horm IGF Res 2005; 15: 185-92.

This is an open access article licensed under the terms of the Creative Commons Attribution Non-Commercial License (http://creativecommons.org/licenses/by$\mathrm{nc} / 3.0 /$ ) which permits unrestricted, non-commercial use, distribution and reproduction in any medium, provided the work is properly cited. 